\title{
Indirect Exposure to Novel Coronavirus (SARS-CoV-2): An Overview of Current Knowledge
}

\author{
Christian Ebere Enyoh ${ }^{1 *}$, Andrew Wirnkor Verla ${ }^{1}$, Wang Qingyue ${ }^{2}$, Dipak Kumar Yadav ${ }^{3}$, Md. Akhter \\ Hossain Chowdhury ${ }^{4}$, Beniah Obinna Isiuku ${ }^{5}$, Tanzin Chowdhury ${ }^{2,5}$, Francis Chizoruo Ibe ${ }^{1}$, Evelyn Ngozi \\ Verla $^{6}$, Toochukwu Oluwatosin Maduka ${ }^{6}$ \\ ${ }^{1}$ Group Research in Analytical Chemistry, Environment and Climate Change (GRACE\&CC), Department of \\ Chemistry, Imo State University (IMSU), PMB 2000 Owerri, Imo State, Nigeria \\ ${ }^{2}$ Graduate School of Science and Engineering, Saitama University, Saitama, Japan \\ ${ }^{3}$ Nobel Medical College Teaching Hospital, Biratnagar, Nepal \\ ${ }^{4}$ Dept. of Agricultural Chemistry, Bangladesh Agricultural University, Mymensingh-2202, Bangladesh \\ ${ }^{5}$ Department of Chemistry, Imo State University (IMSU), PMB 2000 Owerri, Imo State, Nigeria \\ ${ }^{6}$ Department of Environmental Technology, Federal University of Technology, Owerri, Imo State, Nigeria \\ *Corresponding Author: cenyoh@gmail.com
}

\begin{abstract}
This review chronicles the indirect transmission method which seems to be overlooked by most people and makes attempts to clearly document the various transmission ways with a hope that such information may strengthen the knowledge base of researchers towards methods of eradicating the pandemic. Current knowledge of transmission and exposure of SARS-CoV-2 has been explained. Various researchers have put forward different ways of exposure and transmission. Literature does not reveal whether the indirect transmission route is the dominant one. However total lockdown could be a veritable means to reduce both direct and indirect transmission routes. In many countries where the indirect transmission has been reduced, the scourge of the virus is less. The work creates awareness on the need to watch out for those routes of transmissions that may not be popular and suggested key knowledge gaps that needs to filled.
\end{abstract}

Keywords: Air pollution, COVID-19, Human health, Pandemic, Transmission, Wastewater, 


\section{Introduction}

The global pandemic of coronavirus disease 2019 (COVID-19) that is ongoing is caused by severe acute respiratory syndrome coronavirus 2 (SARS-CoV-2) and is currently a public health emergency of international concern (WHO, 2020). As of April $21^{\text {st }}$, 2020, data showed that there are two million, four hundred and ninety thousand, five hundred and sixteen $(2,490,516)$ cases of SARS-CoV-2 infection in 215 countries with the death of one hundred and seventy thousand, five hundred and ninety (170,590) (death rate $6.8 \%$ ) (Worldometer, 2020). This trend is on the continuous increase daily as more cases are being recorded daily, despite the global efforts to stop the outbreak. This, therefore, is responsible for the global lockdown or movement restriction and thus global economy is being affected (Lora et al., 2020). Other efforts to stop the spread involve encouraging proper hygiene which include, hand washing, social distancing and other personal hygiene directives such as avoid face touching especially the eyes, nose and mouth (Enyoh et. al., 2020).

Generally, three possible transmission routes of COVID-19 by the patient to people have been identified including symptomatic, pre-symptomatic and asymptomatic transmission. By way of definition, a symptomatic COVID-19 case is a case that has developed signs and symptoms compatible with COVID-19 virus infection. The presymptomatic transmission occurs during the incubation period (5-14 days) for COVID-19 i.e between the infected time to time when symptoms begin to manifest while the asymptomatic transmission is an infected person without showing any symptoms but transmits the virus to another person. However, to date there are no reports of asymptomatic transmission but few documentation of laboratory-confirmed cases exists (WHO, 2020). The reported symptoms of COVID-19 patients include cough, fever, difficulty in breathing and diarrhea. SARS-CoV-2 ribonucleic acid (RNA) has been detected in feces of not only symptomatic but also asymptomatic patients and on surfaces, in aerosols and wastewater (Gao et al., 2020; Holshue et al., 2020; Jiehao et al., 2020; Tang et al., 2020; Wölfel et al., 2020; Zhang et al., 2020; Ahmed et. al., 2020). ). In other to document clearly the various ways of transmission and exposure for this new virus, we hereby present an overview on the current knowledge on the sources of exposure of human to COVID-19. This will provide an overall quick, concise yet precise reference material both scholars and public office holders for the purpose of public enlightenment and could assist policy makers in formulating policies that would help reduce the spread of this virus. 


\section{Methodology}

Materials such as statistical bulletins, blogs, journals articles and conference/workshop/seminar papers that were published online were used for sourcing information. In other to maintain our idea of current information we focused on publications within the month of March and April 2020. All searches were restricted to articles from peer reviewed articles written in English and focused only on SARS-CoV-2, ignoring previous coronaviruses. Information not backed by empirical data was avoided and interviews were completely left out.

\section{Indirect exposure routes to SARS-CoV-2}

Preventing the transmission in the family settings, public and healthcare systems is of importance to prevent any further spread of the virus. Two possible routes of exposure include the direct or indirect transmission of the virus from an infected person to an uninfected person or a new host.

Direct exposure: Direct exposure is one of the major routes of transmission of coronavirus from person-to-person. This has been described both in hospitals where medical personnel contact the diseases from patient or healthy person contacting the disease from an infected medical personnel. In this case it could said to be a nosocomial infection. Another typical direct exposure route involves family settings (Chan et. al., 2020). Here, a member of the family transmits the virus to one or other members of the same family.

Indirect exposure: Indirect viral transmission involves an uninfected person coming in contact either by hand or with a contaminated surface. Transmission of coronaviruses from contaminated dry has been demonstrated and reviewed (Kampf et. al., 2020). Another indirect route could be from inhaling contaminated air or ingesting, swallowing, and/or breathing in untreated wastewater spray or mist.

The schematic below emphasizes the indirect exposure routes to SARS-CoV-2 based on current information are presented in Figure 1. 


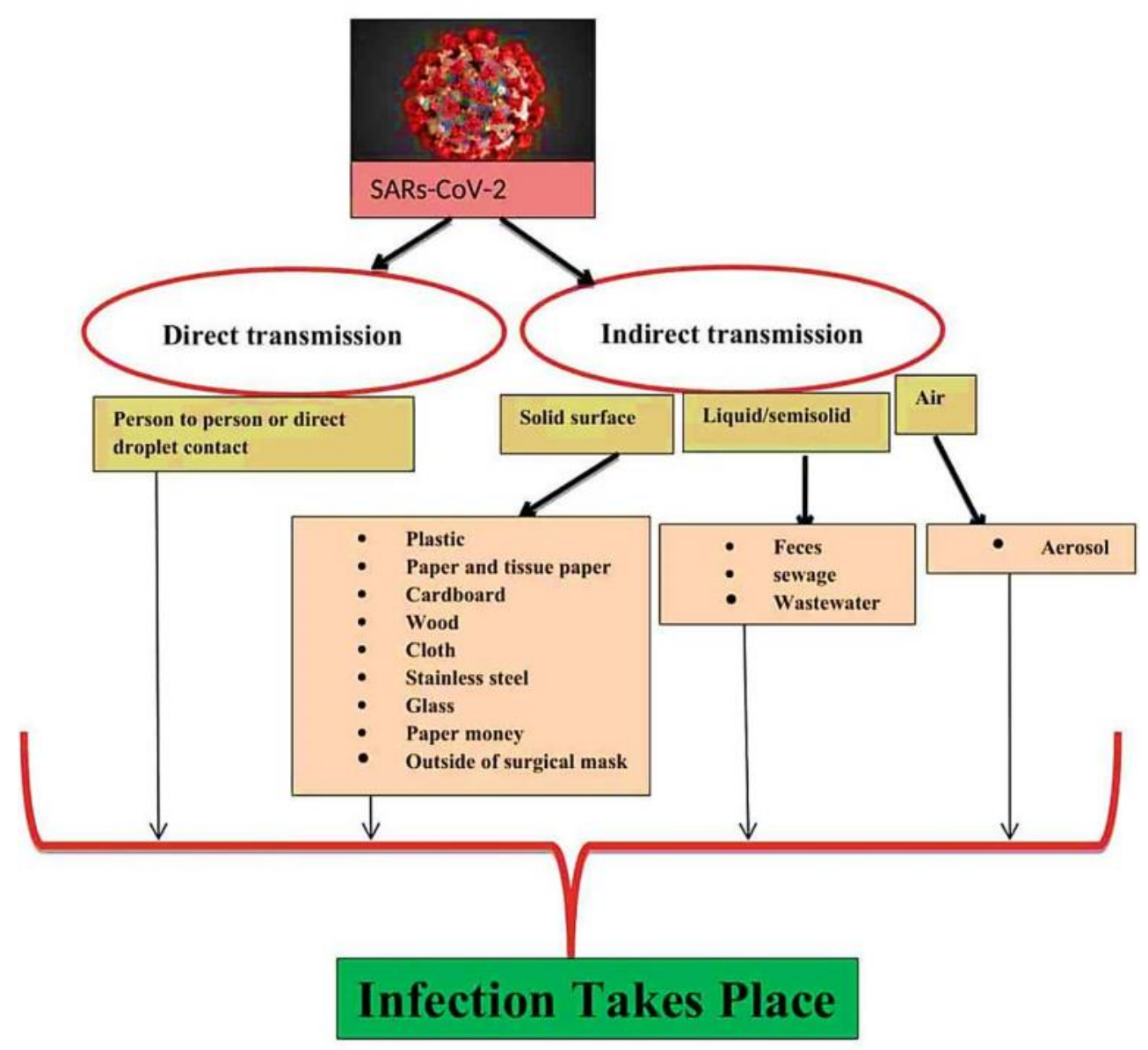

Figure 1. Overview of exposure pathway to SARS-CoV-2 based on current information

\subsection{Solid surfaces/fomites}

This route is based on contact transmission when viral particles emitted from the respiratory tract of an infected individual are deposited on a solid surface such as plastic, paper and tissue paper, cardboard, wood, cloth, stainless steel, glass, paper money and outside of surgical masks. Then the virus can infect another person when the person comes in contact with the contaminated surface by hand and then touches their nose, mouth or eyes, then sneaks into the body via the mucous membranes. The survival of SARS-CoV-2 on surfaces has been shown in some reports, in both laboratory and natural settings. These studies are summarized in Table 1. Santarpia et. al., (2020) found viral particles on surfaces such as toilets, and frequently touched surfaces at the University of Nebraska Medical Center. Similarly, on March 26, the CDC (Center for Disease Control) published a report on the coronavirus-stricken Diamond Princess Cruise ship in which they found traces of RNA from SARS-CoV-2 on surfaces throughout the 
cruise ship, in the cabins of both symptomatic and asymptomatic infected passengers, up to 17 days later (Leah et. al., 2020).

Table 1. Persistence of novel coronavirus on surfaces at different conditions

\begin{tabular}{|c|c|c|c|c|c|c|}
\hline Surface & Strain/ isolate & $\begin{array}{l}\text { Inoculum (Viral } \\
\text { Titer in } \\
\text { TCID }_{50} \text { per } \mathrm{mL} \text { ) }\end{array}$ & $\begin{array}{l}\text { Temperature } \\
\left({ }^{\circ} \mathrm{C}\right)\end{array}$ & RH (\%) & Persistence & Reference \\
\hline Plastics & & & & & $\leq 3$ days & \\
\hline Paper & SARS-CoV-2 & & & & 3 hours & \\
\hline Cardboard & nCoV-WA1- & $10^{5.25}$ & 21 to 23 & 40 & 24 hours & Neeltje et. al., 2020 \\
\hline Stainless steel & $\begin{array}{l}2020 \\
\text { (MN985325.1) }\end{array}$ & & & & $\leq 3$ days & \\
\hline Copper & & & & & 4 hours & \\
\hline Wood & & & & & 4 days & \\
\hline Ceramics & & & & & $\leq 5$ days & WebMD Medical \\
\hline Aluminum & N/A & N/A & N/A & N/A & $2 \leq 8$ hours & Reference (2020) \\
\hline Glass & & & & & $\leq 5$ days & \\
\hline Metal & & & & & $\leq 5$ days & \\
\hline
\end{tabular}

RH: Relative Humidity; N/A: Not available.

In hospital settings, there will be high risks of infection by contact with surfaces especially in low and middle income countries (LMICs) with poor health care systems (Dipak et. al., 2020), where patient's documentation is mostly done using paper-based records. Most of the hospitals in LMICs are using paper to keep patient records, owing to poor funding and lack of proper databases. Each record file is exchanged many times between health care workers, patient caretakers as well as various administrative people in the hospital. These paper files and records also it travels to different wards or rooms for various purposes along with patients during medical check-up and treatment. The virus could be transmitted during this process. At present, very little is known regarding surface distribution of SARS-CoV-2 in hospitals of LMICs which rely on paper documentation of patients. However, this pathway of infection may also occur in public places. In another study, Zhen-Dong et. al., (2020) indicated that surfaces in hospital general wards and intensive care units to be highly infectious of which the highest rates were for computer mice, followed by trash cans, sickbed handrails and doorknobs. The study further revealed that sleeve cuffs and gloves of medical staff presented significant positive results for the virus. Due to these findings, ZhenDong et. al., (2020) encouraged proper hygiene such as proper hand washing or sanitizing be practiced by medical staff immediately after patient contact. 


\subsection{Liquid and/or semisolid}

\subsubsection{Feces/stool}

According to the World Health Organization (WHO, 2003), a significant proportion (16-73\%) of patients with SARS tend to have diarrhea in addition to respiratory symptoms. As one of the symptoms of COVID-19 is diarrhea, the patient tends to excrete feces/stool often. Recent reports show that SARS-CoV-2 has been detected in stool samples of COVID-19 patients (Wang et. al., 2020; Chen et. al., 2020; Holshue et. al., 2020; Xiao et. al., 2020; Xu et. al., 2020; Wu et. al., 2020a) and for more than nine days after the patients recovered (Tang et. al., 2020).

The shedding of SARS-CoV-2 was studied in a cluster of 9 cases and was 10000000 RNA copies/g feces one week after symptom onset and decreased to 1000 RNA copies/g three weeks after symptom onset (Woelfel et. al., 2020). In another study, Zhang et. al. (2020) reported up to 1000000 viral particles per $\mathrm{mL}$ in a single fecal sample. Thereby, revealing the likelihood of infection through contact with contaminated stool or feces, even though, there are currently no reports of infection through this process. Further, because the virus is detectable in the feces just like the previous coronaviruses (Peiris et. al., 2003). Therefore aerosolization of the virus in contaminated feces during toilet flushing was believed to be the mode of transmission of this outbreak similar to the previous coronaviruses (Yu et. al., 2004).

\subsubsection{Wastewater}

By adopting a wastewater - based epidemiology (WBE) approach, the prevalence of viruses in a particular wastewater treatment plant (WWTP) catchment population was understood by researchers because wastewater contains viruses excreted from symptomatic and asymptomatic individuals in a catchment (Xagoraraki and O'Brien, 2020; Ahmed et. al., 2020). The WBE approach is very essential in predicting and providing early warning for a potential outbreak of disease. Therefore, informing the efficacy of public health interventions, as previously demonstrated for enteric viruses, such as norovirus, hepatitis A virus, and poliovirus (Hellmér et al. 2014; Asghar et al., 2014). Recent studies have therefore shown that SARS-CoV-2 is present in untreated wastewater suggesting a significant source or route of infection to the people of most communities (Ahmed et. al., 2020; Wu et. al., 2020; Medema et al., 2020). The presence of SARS-CoV-2 in untreated wastewater is linked to the stool of an infected person passed into the sewer system. In stool samples with high RNA copies, viable SARS-CoV-2 was detected 
(Wang et. al., 2020). Although it is unlikely that wastewater will become an important transmission pathway for coronaviruses like SARS-CoV-2, increasing the circulation of the virus in the population will increase the virus load into the sewer systems of our cities (Medema et al., 2020).

Ahmed et. al., (2020) used N_Sarbeco and NIID_2019-nCOV_N assays in their study for the detection of SARSCoV-2, and subsequently sequencing the RT-qPCR (quantitative reverse transcription polymerase chain reaction) products recorded to avoid false results due to wastewater being a complex matrix. Results showed that $22.2 \%$ ( 2 out of 9) of wastewater samples analyzed were positive for SARS-CoV-2 using the N_Sarbeco assay while NIID_2019-nCOV_N assay failed to detect. Prevalence estimates were calculated according to Eq. (1), which is based on excreted human feces as the sources of SARS-CoV-2 in the wastewater. Results suggest a median SARSCoV-2 infection of $0.096 \%$ in the catchment basin during the period. The clinical prevalence would be equivalent to 450 cases in the catchment, but the upper bound of the $95 \%$ confidence interval around the median would suggest up to 764 total cases to 314 undiagnosed cases or roughly 7 undiagnosed infections for every 10 diagnosed infections.

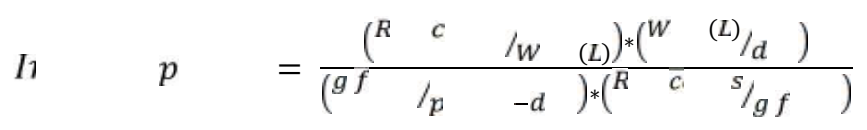

Where Wws = wastewater sample in liters; Wwt = total wastewater collected per day in liters.

By use of PEG 8000 (polyethylene glycol) concentration method, Wu et. al., (2020) were able to recover SARSCoV-2 successfully from wastewater. Following a $24 \mathrm{~h}$ flow-dependent composite sample, the authors assayed using CDC N1, N2, and N3 primers with a virus concentration of $\sim 10$ to 240 Copies $40 \mathrm{~mL}^{-1}, \sim 40$ to $140 \mathrm{Copies}^{-10 \mathrm{~mL}^{-1}}$ and $\sim 10$ to 160 Copies $40 \mathrm{~mL}^{-1}$. The prevalence rate was estimated to range from 0.000001 to $0.000035 \%$. Similarly, Medema et al., (2020) followed a 24h flow-dependent composite sampling technique in collecting tested sewage samples of 7 cities in the Netherland. With the use of RT-PCR against three fragments of the nucleocapsid protein gene $\left(\mathrm{N}_{1-3}\right)$ and one fragment of the envelope protein gene $(\mathrm{E})$, the samples were analyzed. No SARS-CoV-2 detected in samples with $\mathrm{N}_{2}$ throughout the study period while others had a detection rate of $58.3,33.3$ and $20.8 \%$ respectively. The prevalence rate was estimated to range from 0.000001 to $0.000035 \%$ (Table 2).

Overall, the information provided by these studies shows that not only there is risk to sewage workers but also the circulating SARS-CoV-2 in the communities can be monitored through the sewage surveillance. Thereby, 
complementing the limited current clinical surveillance done in many world countries (e.g mostly low and middle income countries), where tests are mainly done when there are severe symptoms. Furthermore, it could be used as an early warning tool for increased circulation in the rainy period on unaffected populations. However, there is no evidence to date that SARS-CoV-2 has been transmitted via sewerage systems, with or without wastewater treatment (CDC, 2020; WHO, 2020a). We, therefore, recommend that future wastewater sampling efforts and analysis adhere to already established safety procedures to curb the potential spread. 
Table 2. Available data on the detection of SARS-CoV-2 in wastewater samples

\begin{tabular}{|c|c|c|c|c|c|c|c|}
\hline Location & Sampling date & Sampling technique & Assay used & $\begin{array}{l}\text { Detection } \\
\text { rate }(\%)\end{array}$ & $\begin{array}{l}\text { Virus concentration } \\
\left({ }^{\mathrm{a} C o p i e s} / 100 \mathrm{~mL}\right. \\
\left.{ }^{\mathrm{b}} \text { Copies } / 40 \mathrm{~mL}\right) \\
\end{array}$ & $\begin{array}{l}\text { Prevalence } \\
\text { rate }(\%)\end{array}$ & References \\
\hline $\begin{array}{l}\text { Southeast } \\
\text { Queensland, } \\
\text { Australia }\end{array}$ & $24 / 02 / 20$ to $01 / 04 / 20$ & 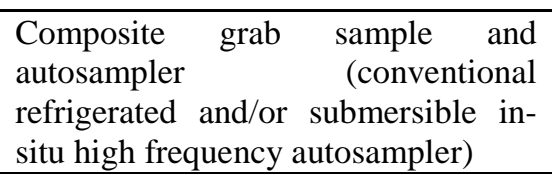 & $\begin{array}{l}\text { N_Sarbeco } \\
\text { NIID_2019-nCOV_N }\end{array}$ & $\begin{array}{l}22.2 \\
0\end{array}$ & $\begin{array}{l}\text { Approx. } 1.90 \text { to } 12.0^{\mathrm{a}} \\
\text { ND }\end{array}$ & $\begin{array}{l}0.096 \\
\text { N/A }\end{array}$ & $\begin{array}{lll}\text { Ahmed } & \text { et. } & \text { al., } \\
2020 & & \end{array}$ \\
\hline $\begin{array}{l}\text { Massachusetts, } \\
\text { USA }\end{array}$ & $18 / 03 / 20$ to $25 / 03 / 20$ & $\begin{array}{l}\text { 24h flow-dependent composite } \\
\text { sample }\end{array}$ & $\begin{array}{l}\mathrm{CDC} \mathrm{N}_{1} \\
\mathrm{CDC} \mathrm{N}_{2} \\
\mathrm{CDC} \mathrm{N}_{3}\end{array}$ & $\begin{array}{l}\text { N/A } \\
\text { N/A } \\
\text { N/A }\end{array}$ & $\begin{array}{l}\text { Approx. } 10 \text { to } 240^{\mathrm{b}} \\
\text { Approx. } 40 \text { to } 140^{\mathrm{b}} \\
\text { Approx. } 10 \text { to } 160^{\mathrm{b}}\end{array}$ & $\begin{array}{l}0.026 \\
0.026 \\
0.026\end{array}$ & Wu et. al., 2020 \\
\hline $\begin{array}{l}7 \text { locations in } \\
\text { Netherlands }\end{array}$ & $5 / 02 / 20$ to $5 / 03 / 20$ & $\begin{array}{l}\text { 24h flow-dependent composite } \\
\text { sample }\end{array}$ & $\begin{array}{l}\text { CDC N } \\
\mathrm{CDC} \mathrm{N}_{2} \\
\mathrm{CDC} \mathrm{N}_{3} \\
\text { E_Sarbeco }\end{array}$ & $\begin{array}{l}58.3 \\
0 \\
33.3 \\
20.8\end{array}$ & $\begin{array}{l}\text { N/A } \\
\text { N/A } \\
\text { N/A } \\
\text { N/A }\end{array}$ & $\begin{array}{l}0.000001 \\
\text { N/A } \\
0.000035 \\
0.000035\end{array}$ & $\begin{array}{l}\text { Medema et al., } \\
2020\end{array}$ \\
\hline
\end{tabular}

*Primer probe were CDC $\mathrm{N}_{1}, \mathrm{~N}_{2}, \mathrm{~N}_{3}=$ nucleocapsid protein gene ( $\left.\mathrm{N}_{1-3}\right)$ (USA); Sarbeco $\mathrm{N}$ = envelope protein gene (N) and $\mathrm{E}=$ envelope protein gene (E); NIID_2019-nCOV_N (Japan)

$* \mathrm{~N} / \mathrm{A}=$ Not available $; \mathrm{ND}=$ No data 


\subsection{Air}

The transmission of SARS-CoV-2 in the air is aided by aerosols as people emit aerosol particles when talking, and that louder speech volumes correlate to more aerosol particles being emitted. The transportation of aerosols is largely depended on environmental factors such as air flow and direction, humidity, ambient temperature, wind speed and gravity as well as landscape and densities of buildings (Opara et al. 2016; Ibe et al, 2020; Enyoh et. al., 2019; 2020 Ma et. al., 2020). Recent studies have demonstrated this scenario of SARS-CoV-2 surviving in aerosols (Neeltje et. al., 2020; Zhen-Dong et. al., 2020). Neeltje et. al., (2020) used the SARS-CoV-2 nCoV-WA1-2020 (MN985325.1) strain in their study and compared the stability in aerosols $(<5 \mu \mathrm{m})$. Using a three-jet nebulizer, the aerosol was filled with viruses with $50 \%$ tissue-culture infectious dose; $\operatorname{TCID}_{50} \mathrm{~mL}^{-1}$ of $10^{5.25}$. The decay rate was determined to measure stability at different environmental conditions such as temperature $\left(21\right.$ to $\left.23{ }^{\circ} \mathrm{C}\right)$ and relative humidity of $40 \%$. Results showed SARS-CoV-2 was stable and remained throughout the period of study (three hours). In hospital setting, Zhen-Dong et. al., (2020) collected air samples in intensive care units (12 air supplies and 16 air discharges hour ${ }^{-1}$ ) and general wards ( 8 air supplies and 12 air discharges hour ${ }^{-1}$ ). Results from the study showed that $35 \%$ and $12.5 \%$ of the air samples were contaminated respectively, indicating that the virus can travel in air. Overall, the aerosol mainly concentrated downstream up to 13 feet from the source while smaller quantities were found up to 8 feet upstream with the maximum transmission of $\sim 4$ meters from the source.

Reviewed studies have confirmed that SARS-CoV-2 aerosol exposure poses significant risks. Therefore, there is a need for more studies on indoor and outdoor environments where many environmental factors are in play such as the presence of airborne microplastics and other particles in the ambient environment that may aid in the transmission of the virus over longer distances (> $4 \mathrm{~m})$.

While indoor activities are ongoing, whether in the hospital or household setting, large volume/quantity of small size plastics (microplastics or nanoplastics) are often generated and deposited (could be as high as $>11,000$ particles day $^{-1} \mathrm{~m}_{2}^{-1}$ ) on ground surfaces (Enyoh et. al., 2019). Virus emitted from a patient can drop on the surface of these particles and can be accommodated up to 3 days, if the room isn't cleaned properly. During the period of accommodation, the particles can be re-suspended in the air with dust particles when there is disruption of indoor air, thereby putting inhabitant at risks of infection when these plastic particles (with the virus) are inhaled. Following a simulated study, MPs particles as much as 272 particles can be inhaled by inhaling indoor air (Vianello et. al., 
2019). In the outdoor environment, the process is similar except that the virus may potentially be transported with particles over long distances depending on the wind events, relative humidity, ambient temperature and anthropogenic activities as well as particle shape, size and length (Enyoh et. al., 2019; 2020).

\section{Conclusion, recommendation and further studies}

\subsection{Conclusions and recommendation}

- SARS-CoV-2 can be transmitted indirectly through contact with solid surfaces or fomites, liquid or semisolids including wastewater and feces as well as through air (aerosol). Although reports have not shown any case transmitted through these pathways, the likelihood is high as suggested by available data.

- Wastewater Based Epidemiology (WBE) may be an effective tool in monitoring outbreaks of this virus and there is a need to treat wastewater before disposing of in the environment.

- The primer probe used in wastewater studies included N_Sarbeco, E_Sarbeco, NIID_2019-nCOV_N, and CDC $\left(\mathrm{N}_{1-3}\right)$ of which CDC $\mathrm{N}_{2}$ and NIID_2019-nCOV_N have poor detection rate.

- The virus can be transported in the air up to $4 \mathrm{~m}$ from the source, therefore the need to review or reevaluate the current guideline of keeping $2 \mathrm{~m}$ distance between people as recommended by WHO.

\subsection{Further studies}

- Further studies should focus on the contribution of airborne plastic particles such as MPs and NPs on the survival and transport of the virus in air over long distances.

- Studies should also be conducted on the survival of the virus in drinking water as previous coronaviruses have been shown to survive (Gundy et. al., 2009).

- As people died from COVID-19, they are buried in soil. So, the potential impact on ground water should be studied.

These studies would inform on the extent of risks of exposure and damage this unwanted virus would cause to the public and ecosystems health. 


\section{Conflict of interest}

The authors declares no conflict of interest

\section{References}

Ahmed W, Nicola A, Janette E, Kyle B, Aaron B, Jake WO, Phil MC, Masaaki K, Stuart LS, Jiaying L, Ben T, Rory V, Wendy JMS, Julian Z, Leanne D, Philip H, Kevin VT, Jochen FM (2020). First confirmed detection of SARSCoV-2 in untreated wastewater in Australia: A proof of concept for the wastewater surveillance of COVID-19 in the community, Science of the Total Environment, https://doi.org/10.1016/j.scitotenv.2020.138764

CDC (2020). Water Transmission and COVID-19. Assessed 20/04/20. https://www.cdc.gov/coronavirus/2019 ncov/php/water.html

Enyoh CE, Verla AW, Verla EN (2020). Novel Coronavirus (SARS-CoV-2) and Airborne Microplastics. Zenodo. http://doi.org/10.5281/zenodo.3738452

Enyoh CE, Verla AW, Verla EN, Ibe FC, Amaobi CE (2019). Airborne microplastics: a review study on method for analysis, occurrence, movement and risks. Environ. Mon. and Assess;, 191(668):1-11. https://doi.org/10.1007/s10661-019-7842-0

Gundy PM, Charles PG, Ian LP (2009). Survival of Coronaviruses in Water and Wastewater. Food Environ Virol, 1:10-14. https://10.1007/s12560-008-9001-6

Ibe FC, Opara AI, Duru CE, Isiuku BO, Enedoh MC. (2020). Statistical analysis of atmospheric pollutant concentrations in parts of Imo State, Southeastern Nigeria. Scientific African, 7 (e00237):1 - 27.

Kampf G, Todt D, Pfaender S, Steinmann E (2020). Persistence of coronaviruses on inanimate surfaces and their inactivation with biocidal agents. Journal of Hospital Infection, 104, 246-251. https://doi.org/10.1016/j.jhin.2020.01.022

Leah FM, Mateusz MP, Barbara JM, Ekaterina VK, Barbara K Erin LM, Nicki P, Dale R, David F, Miwako K, Mitsuru T, Paul TC, Tara S, Eric SH, Nicole JC, Lauren S, Debra AW, Alexandra MM, Gary G, Joanna JR, Kara T, Stefanie W, Christina M, Cynthia Y, Beth W, Amy F, Sara N, Ryan TN, David D, Michelle W, Anna A, Carolyn H, Bryan KK, Kathleen RJ, Katherine L, Atsuyoshi I, John S, Erik S, Tricia B, Christine W, Julia C, Riley W, Andrea S, Paul SM, Elizabeth K, Stefanie C, Rachel M, Paul W, Martin C, Cindy RF (2020). Public Health Responses to COVID-19 Outbreaks on Cruise Ships - Worldwide, February-March 2020. MMWR Morb Mortal Wkly Rep; 69:347-352. DOI: http://dx.doi.org/10.15585/mmwr.mm6912e3external icon.

Lora J, David B, Daniele P (2020). Corona virus: A visual guide to the economic impact. BBC News. Assessed 24/03/2020 http://www.bbc.com/news/usiness-51706225.

Ma Y, Yadong Z, Jiangtao L, Xiaotao H, Bo W, Shihua F, Jun Y, Jingping N, Ji Z, Bin L (2020). Effects of temperature variation and humidity on the death of COVID-19 in Wuhan, China. Science of the Total Environment 724, 138226: 1-7. https://doi.org/10.1016/j.scitotenv.2020.138226

Medema G, Heijnen L, Elsinga G, Italiaander R (2020). Presence of SARS-Coronavirus-2 in sewage. medRxiv. https://doi.org/10.1101/2020.03.29.20045880. 
Opara AI, Ibe FC, Njoku PC, Alinnor JI, Enenebeaku CK (2016). Geospatial and geostatistical analyses of particulate matter $\left(\mathrm{PM}_{10}\right)$ concentrations in Imo State, Nigeria, International Letters of Natural Sciences, 57, 89107.

Peiris JSM, Chu CM, Cheng VCC et al. (2003). Clinical progression and viral load in a community outbreak of coronavirus-associated SARS pneumonia: a prospective study,” The Lancet, 361(9371):1767-1772.

Santarpia JL, Danielle N Rivera, Vicki Herrera, M. Jane Morwitzer, Hannah Creager, George W. Santarpia, Kevin K Crown, David Brett-Major, Elizabeth Schnaubelt, M. Jana Broadhurst, James V. Lawler, St. Patrick Reid, John J. Lowe (2020). Transmission Potential of SARS-CoV-2 in Viral Shedding Observed at the University of Nebraska Medical Center. Medxriv. https://doi.org/10.1101/2020.03.23.20039446

Tang A, Zhen-dong T, Hong-ling W, Ya-xin D, Ke-feng L, Jie-nan L, Wen-jie W, Chen Y, Meng-lu Y, Peng L, Jian-bo Y (2020). Detection of Novel Coronavirus by RT-PCR in Stool Specimen from Asymptomatic Child, China. Emerging Infec. Dis. 26(6): 1-3. https://doi.org/10.3201/eid2606.200301

USEPA (2020). Coronavirus and Drinking water and Wastewater. Coronavirus Assessed 21/04/2020 from https://www.epa.gov/coronavirus/coronavirus-and-drinking-water-and-wastewater.

Vianello, A., Rasmus, L. J., Li, L., Jes, V. (2019). Simulating human exposure to indoor airborne microplastics using a breathing thermal manikin. Scientific Reports, 9, 8670. https://doi.org/10.1038/s41598-019-45054-w.

Wang W, Xu Y, Gao R, et al. (2020). Detection of SARS-CoV-2 in Different Types of Clinical Specimens. JAMA, doi:10.1001/jama.2020.3786

WebMD Medical Reference (2020). How Long Does the Coronavirus Live on Surfaces? Assessed 22/04/2020. https://www.webmd.com/lung/how-long-covid-19-lives-on-surfaces

WHO (2003). Issues consensus document on the epidemiology of SARS. Wkly Epidemiol Rec. 78: 373-75.

WHO (2020). Statement on the second meeting of the International Health Regulations (2005) Emergency Committee regarding the outbreak of novel coronavirus (2019-nCoV).

WHO (2020a). Water, sanitation, hygiene, and waste management for the COVID-19 virus, World Health Organisation:6

Wu, F., Xiao, A., Zhang, J., Gu, X., Lee, W., Kauffman, K., Hanage, W., Matus, M., Ghaeli, N., Endo, N., Duvallet, C., Moniz, K., Erickson, T., Chai, P., Thompson, J., Alm, E., 2020 a. SARS-CoV-2 titers in wastewater are higher than expected from clinically confirmed cases, medRxiv. https://doi.org/10.1101/2020.04.05.20051540.

Wu, Y., Guo, C., Tang, L., Hong, Z., Zhou, J., Dong, X., Yin, H., Xiao, Q., Qu, X., Kuang, L., Fang, X., Mishra, N., Lu, J., Shah, H., Jiang, G., Huang, X., (2020a). Prolonged presence of SARS -CoV -2 viral RNA in faecal samples. Lancet Gastroenterol. Hepatol. 5 (5), 434 - 435.

Xagoraraki, I., O'Brien, E (2020). Wastewater -based epidemiology for early detection of viral outbreaks, in: O'Bannon, D. (Ed.), Women in Water Quality. Springer Nature Switzerland, pp. $75 \quad-97$. https://doi.org/10.1007/978-3-030-17819-2.

Yu ITS, Li Y, Wong TW et al., (2004). Evidence of airborne transmission of the severe acute respiratory syndrome virus. New England J. of Med., 350(17):1731-1739. 
Zhang N., Y. Gong, F. Meng, Y. Bi, P. Yang, F. Wang, (2020). Virus shedding patterns in nasopharyngeal and fecal specimens of COVID-19 patients. medRxiv, in press, doi:10.1101/2020.03.28.20043059

Zhen-Dong G, Wang ZY, Zhang SF, Li X, Li L, Li C, et al. (2020). Aerosol and surface distribution of severe acute respiratory syndrome coronavirus 2 in hospital wards, Wuhan, China. Emerg Infect Dis. https://doi.org/10.3201/eid2607.200885 